\title{
PERANCANGAN APLIKASI PENDATAAN DATA KEPEGAWAIAN NEGERI SIPIL PADA DINAS KOMUNIKASI DAN INFORMATIKA KOTA METRO
}

\author{
Lia Sari ${ }^{(1)}$ Guna Yanti Kemala Sari Siregar ${ }^{(2)}$ \\ Jurusan Ilmu Komputer, Fakultas Ilmu Komputer,Universitas Muhammadiyah Metro \\ Jl.Gatot Subroto No.100 Yosodadi Kota Metro, Telpon :(0725)42445-Fax(0725)42454 \\ E-mail: gunayanti2017@gmail.com
}

\begin{abstract}
Abstrak
Perancangan aplikasi pendataan data kepegawaian negeri sipil di Dinas Komunikasi dan Informatika saat ini meliputi pendataan pegawai, [engolahan data, prosedur, tata kerja, sumber daya manusia, dan teknologi computer untuk menghasilkan informasi yang cepat, lengkap dan akurat dalam rangka mendukung kegiatan administrasi kepegawaian. Penyimpanan pegawai merupakan hal yang pokok dalam masalah kepegawaian terutama dalam mencari atu merubah data pegawai untuk kemudian di rubah sesuai dengan kebutuhan aplikasi. Aplikasi system informasi kepegawaian ini dibuat menggunakan metode penelitian deskriptif dengan jenis penelitian studi kasus pada Dinas Komunikasi dan Informatika Kota Metro. Dimana teknik pengumpulan data yang digunakan antara lain observasi, wawancara. Untuk metode analisis dan perancangan yang digunakan dalam pembuatan system menggunakan Erd sebagai model data dan DFD sebagai model proses. Berdasarkan hasil pengamatan disimpulkan bahwa memungkinkan terjadinya keterlambatan dan proses manipulasi data dan keterlambatan setiap tampilan data yang muncul. Sedangkan berdasarkan pengamatan menyimpulkan bahwa system dinilai sudah cukup baik, dapat di pelajari, mudah digunakan.
\end{abstract}

Kunci : Perancangan ,Aplikasi ,Pengolahan data, Dinas komunikasi dan informatika

\section{PENDAHULUAN}

Teknologi dan Informasi merupakan dua hal yang tidak dapat dipisah saat ini. Hal ini terlihat dari proses untuk mendapatkan informasi yang dapat diperoleh secara cepat, tepat dan akurat dengan didukung oleh kemajuan teknologi yang semakin canggih. Kemajuan teknologi ini membuat banyak organisasi dan lembaga pendidikan menggunakan teknologi berbasis komputer dan jaringan untuk membantu pekerjaanya karena bersifat efektif dan efisien. Dinas Komunikasi dan Informatika merupakan salah satu Dinas Komunikasi dan Informatika yang berada di Kota Metro, kondisi saat ini pada Dinas Komunikasi dan Informatika Kota Metro ditemui permasalahan yang dihadapi yaitu dalam melakukan perekapan data pegawai yang sudah menggunakan sistem pendataan secara terkomputerisasi, ini terlihat dari 
penggunaan Ms.Excel dalam melakukan pendataan pegawai pada Dinas Komunikasi dan Informatika Kota Metro. Sehingga proses tersebut mempunyai kerumitan tersendiri terkait dengan sistem yang digunakan. Dinas Komunikasi dan Informatika Kota Metro adalah intansi yang dibentuk berdasarkan Undang-undang Nomor 12 Tahun 1999 yang peresmiannya dilakukan di Jakarta pada tanggal 27 April 1999. Struktur Organisasi Pemerintah Kota Metro pada mulanya dibentuk melalui Peraturan Daerah Nomor 1 Tahun 2001 yang terdiri dari 9 Dinas Otonom Daerah, yaitu: 10 Bagian Sekretariat Daerah, 4 Badan dan 2 Kantor.Dalam perkembangan berikutnya, dengan terbitnya Peraturan Pemerintah Nomor 8 Tahun 2003, Pemerintah Daerah Kota Metro melakukan penataan organisasi Perangkat Daerah sebagaimana diatur dalam Perda Nomor 3 Tahun 2003 tentang Pembentukan Susunan Organisasi dan Tata Kerja Perangkat Daerah.Berikut kandungan ayat suci Alqur'an Surat An Nisa ayat 9 tentang komunikasi:

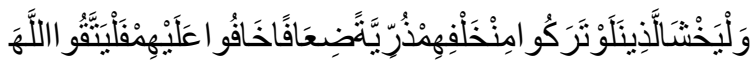

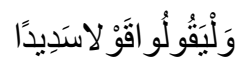

"Dan hendaklah takut (kepada Allah) orangorang yang sekiranya mereka meninggalkan keturunan yang lemah dibelakang mereka, yang mereka khawatirkan terhadap (kesejahteraannya)nya. Oleh sebab itu, hendaklah mereka bertaqwa kepada Allah dan hendaklah mereka berbicara dengan tutur kata yang benar (qaulan sadida)". Sistem pendataan pegawai pada Dinas Komunikasi dan Informatika sudah terkomputerisasi dalam data pegawai diolah menggunakan Ms.Excel,data pegawai dalam penulisan dan pembuatan tabel pendataan pegawai tersebut terkadang terjadi kesalahan, pencarian data pegawai kurang efektif karena harus mencari satu persatu data pegawai pada Ms.Excel yang kurang efisien waktu, hal ini dapat menyebabkan proses pendataan pegawai serta pembuatan laporan data pegawai kurang efektif. Pendataan data pegawai merupakan salah satu bentuk perangkat lunak yang dapat menyampaikan informasi tentang data kepangkatan. Pada saat ini pendataan data pegawai yang diterapkan di Dinas Komunikasi dan Informatika Kota Metro memang sudah terkomputerisasi, namun penggunanya masih standar umum. Berdasarkan hal tersebut, maka penulis mencoba untuk membuat suatu perancangan sistem pendataan pegawai, sehingga dalam pencarian data pegawai dapat lebih mudah 
sehingga tidak adanya keterlambatan dalam penyampaian informasi. Jadi diperlukan adanya sistem pendataan pegawai dalam bentuk sebuah aplikasi yang dapat mempermudah pekerjaan dan mampu menyajikan data atau informasi yang sesuai kebutuhan. Atas pertimbangan uraian diatas, maka penulis ingin mengajukan sebuah tugas akhir dengan judul "Perancangan Aplikasi Pendataan Data Kepegawaian Negeri Sipil Pada Dinas Komunikasi dan Informatika Kota Metro".

\section{KAJIAN PUSTAKA DAN LANDASAN TEORI}

\subsection{Defisini Perancangan}

Perancangan merupakan suatu strategi untuk memecahkan masalah dan mengembangkan solusi terbaik permasahalan itu. Perancangan juga dapat diartikan sebagai tahapan proses pengembangan spesifikasi sistem yang memiliki tujuan untuk mendesain sistem baru berdasarkan rekomendasi analisis sistem. Menurut Ladjamudin (2005:39) menyimpulkan bahwa: "Perancangan adalah tahapan perancangan (design) memiliki tujuan untuk mendesain sistem baru dapat menyelesaikan masalah-masalah yang dihadapi perusahan yang diperoleh dari pemilihan alternatif sistem yang terbaik".

\subsection{Definisi Aplikasi}

Menurut Jogiyanto [2005] Aplikasi adalah penggunaan dalam suatu komputer, instruksi (instructiom) atau pernyataan (statement) yang disusun sedemikian rupa sehingga komputer dapat memproses input menjadi output. Menurut Harip Santoso Aplikasi adalah suatu kelompok file (Form, Class, Report) yang bertujuan untuk melakukan aktivitas tertentu yang saling terkait.

Menurut Azhar [2004], Aplikasi adalah perangkat lunak yang digunakan untuk tujuan tertentu seperti mengatur Windows, Permainan, Dll.

\subsection{Definisi Data}

Data dapat dikatakan sebagai sesuatu yang belum mempunyai arti bagi penerimaannya dan masih memerlukan adanya suatu pengolahan. Data bisa berwujud suatu keadaan, gambar, suatu, huruf, angka, matematika, bahasa atau simbol-simbol lainnya yang bisa kita gunakan sebagai bahan untuk melihat lingkungan, objek, kejadian ataupun suatu konsep. Menurut Wilkinson (1992:3) menyatakan bahwa: "Data yaitu berisi fakta, angka, bahkan simbol mentah. Secara bersama-sama merupakan masukan bagi suatu sistem informasi”. Menurut Kadir (2009:3) menyatakan bahwa "Data adalah Deskripsi tentang benda, kejadian, aktivitas dan transaksi yang tidak mempunyai makna atau tidak berpengaruh secara langsung kepada pemakai". Dari beberapa pengertian diatas maka dapat diambil kesimpulan bahwa data adalah suatu bahan mentah dari sebuah fakta yang terjadi, bisa berupa angka, benda, kejadian, yang belum diolah pemakai sehingga belum diolah pemakai sehingga belum memiliki arti atau informasi apapun bagi penerimanya.

\subsection{Definisi Pendataan}

Pendataan menurut KBBI (Kamus Besar Bahasa Indonesia)merupakan suatu proses pengumpulan data atau pencarian data. Kenyataan ini menggambarkan suatu kejadian-kejadian nyata, yaitu mengumpulkan semua data yang diperlukan, mengolah dan menyajikan data sesuai yang diharapkan. 


\subsection{Pengertian Pegawai}

Pengertian Pegawai Negeri Sipil (PNS) adalah "Orang yang bekerja pada Pemerintah atau Negara". Dapat disimpulkan bahwa Pegawai Negeri Sipil (PNS)adalah Warga Negara Indonesia yang bekerja pada suatu Intansi Pemerintah serya mengabdikan dirinya pada Negara dan menjadi abdi masyarakat kemudian diangkat berdasarkan perundang undangan yang berlaku.

\subsection{IDE Visual Basic 6.0}

Visual Basic adalah bahasa pemrograman event-driven generasi ketiga dan Integrated Development Environment (IDE) dari Microsoft yang mulai diperkenalkan pada tahun 1991. Dilihat dari sejarahnya, Visual Basic merupakan salah satu bahasa pemgrograman legendaris karena sudah dikembangkan sejak lama dan masih bertahan hingga hari ini. Visual Basic berasal dari pengembangan bahasa BASIC (Beginner All-purpose Symbolic Intruction Code) pada awal tahun 1960 di Dartmouth College, Amerika Serikat. Diawali dengan lahirnya komputer pribadi (Personal Computer atau PC) pertama, bermerek MITS Altair pada tahun 1975. Bill Gates dan Paul Allen menciptakan bahasa pemrograman BASIC untuk Altair. Fasilitas untuk mengakses berbagai macam basis data, serta tidak memerlukan komputer dengan spesifikasi yang terlalu high-end membuat versi ini masih diminati dalam waktu-waktu sekarang. Visual Basic merupakan sebuah bahasa pemrograman yang bersifat eventdrivendan menawarkan Integrated Development Environment (IDE) visual untuk membuat program aplikasi berbasis sistem operasi Microsoft Windows dengan menggunakan model pemrograman Common Object Model (COM).

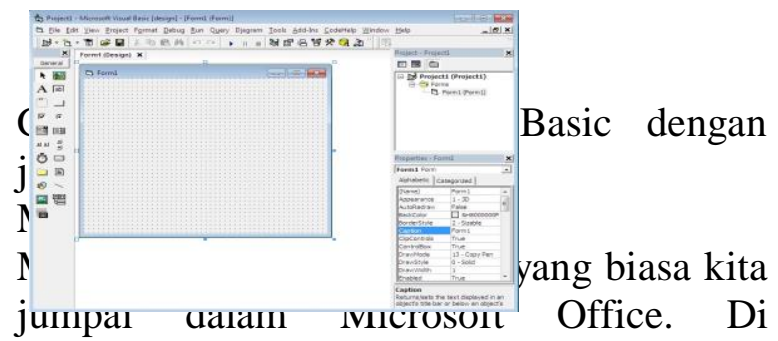
dalamnya terdapat menu file, edit, view, project, format, dan yang lain-lain yang berungsi untuk mengoperasikan program Visual Basic 6.0.

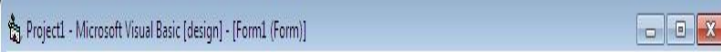

Gambar 2.2 Menu Bar

Main Toolbar

Digunakan untuk melakukan tugas-tugas tertentu dengan cepat.

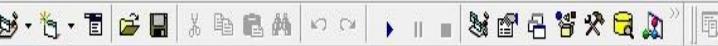

Gambar 2.3 Toolbar

Jendela Toolbox

Jendela ini berisi semua objek atau kontrol yang dibutuhkan untuk membuat suatu program aplikasi. Kontrol adalah suatu nhiek vano akan menjadi interface

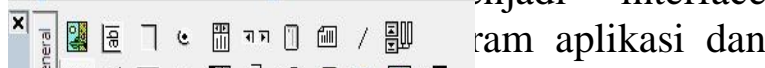

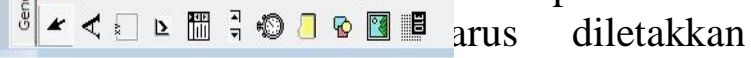
didalam jendela form.

Gambar 2.4 Toolbox

Form

Form sering disebut dengan GUI (Graphical User Interface), adalah sebuah objek yang digunakan untuk menetapkan objek-objek dari toolboox.

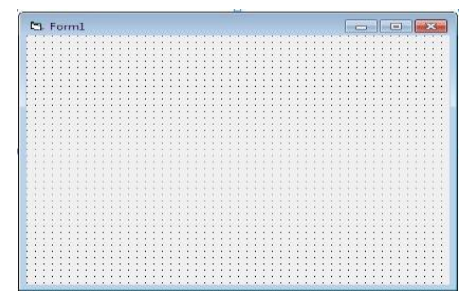


Gambar 2.5 Form

Form kode

Merupakan tempat menulis coding atau syntax program aplikasi.

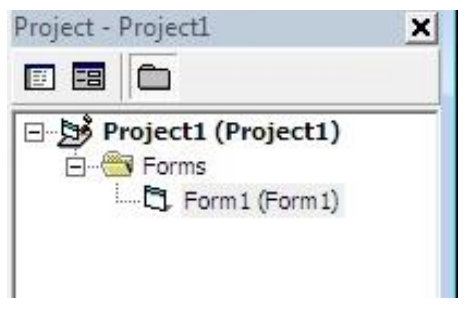

Gambar 2.6 Form kode

Form layout Windows

Merupakan jendela yang digunakan untuk mengatur posisi form pada layar monitor saat program dijalankan.

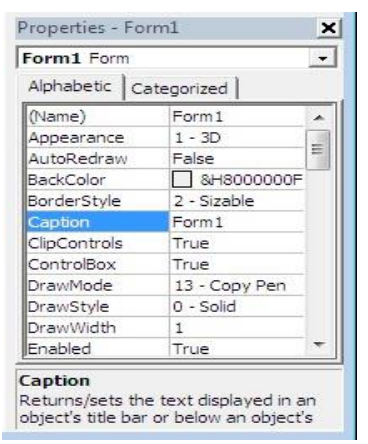

Gambar 2.7 Form layout Windows

Project Windows

Project windows adalah sebuah windows yang menampung project dan form. Di dalamnya juga terdapat icon view code(untuk menampilkan area text editor) dan icon view object( untuk menampilkan GUI).

Properti Windows

Properti windows adalah sebuah windows yang digunakan untuk memodifikasi objek berupa mengubah caption, memberi nama objek, mengubah warna, ukuran, model dan sejenisnya.

\subsection{Tipe Data}

Secara sederhana tipe data dapat didefinisikan dengan istilah tempat untuk menentukan pemberian nilai terhadap suatu variabel sesuai atau tidak dengan nilai yang diberikan oleh user.

Macam-macam Tipe Data :

Tipe Data Numeric Integer

Tipe Data Numeric Integer merupakan tipe data bilangan bulat yang hanya mengenal bilangan desimal. Dimana tipe data Integer tidak mengenal pecahan.

Tipe Data Real

Tipe data numeric real adalah tipe data dari suatu tanda pengenal selain mengenai bilangan bulat utuh tipe data ini juga mengenai nilai angka yang mengenal pecahan.

Tipe Data String

Tipe data string merupakan salah satu jenis tipe data selain mengenai angka disini tipe data dapat juga mengenal data berupa huruf maupun tanda baca.

Tipe Data Char

Secara fungsi tipe data char sama dengan tipe data string tetapi dari segi.

\subsection{XAMPP}

Untuk sebuah aplikasi berbasis web dengan menggunakan bahasa $P H P$, tentu saja diperlukan sebuah server web dan interperen PHP. Server tidak harus sebuah komputer khusus dengan kinerja tinggi dan berukuran sangat besar, tetapi bisa dibuat $P C$ yang mempunyai fungsi selayaknya sebuah web server yaitu, dengan menginstal paket XAMPP. XAMPP merupakan paket $P H P$ dan MySQL berbasis open source yang dapat digunakan sebagai tool pembantu pengembangan aplikasi berbasis $P H P$. $X A M P P$ mengombinasikan beberapa paket 
perangkat lunak berbeda kedalam satu paket. Sampai XAMPP versi 1.7.4, beberapa paket yang dibundel adalah sebagai berikut: Apche HTTPD, mod_autoindex_color module, FileZilla FTP Server, Mercuty Mail Transport Agent, OpenSSL, SQLit, Thr Webalizer, msmtp ( a sendmail compatible SMTP client), MySQL, PrimeBase XT Storage Engine for MySQL, PHP, eAccelerator extension, Xdebug extension, Mig extension, pdflib Lite Extension, PEAR, phpMyAdmin, FPDF libary, ADOdb, Pelr, CPAN, PPM, mod_pert, Apache::ASP.

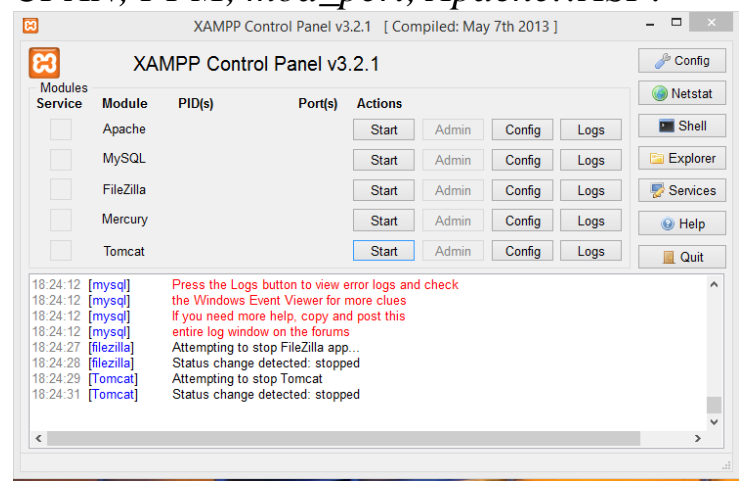

Gambar 2.8 XAMPP

\subsection{Crystal Report}

Menurut Madcoms (2010:234) Crystal Report merupakan program yang terpisah dengan program Microsoft Visual Basic, tetapi keduanya dapat dihubungkan (linkage). Crystal Report merupakan piranti standart untuk pembuatan laporan pada sistem operasi windows, dimana cetakan / template laporan yang dihasilkan dapat disertakan pada banyak bahasa pemrogramman. Crystal report merupakan program khusus untuk membuat laporan yang terpisah dengan program visual basic tetapi keduanya dapat dihubungkan (linkage).Mencetak dengan crystal report hasilnya lebih baik dan lebih mudah karena pada crystal report banyak tersedia objekobjek maupun komponen yang mudah digunakan.

\subsection{Basis Data}

Berikut ini merupakan penjelasan dari beberapa ahli tentang penjelasan basis data yaitu:

Sri Widianti (2009:2) menyatakan : "Basis data adalah suatu kumpulan data terhubung yang disimpan secara bersama-sama pada suatu media, tanpa adanya suatu kerangkapan data, sehingga mudah untuk digunakan kembali, dapat digunakan oleh satu atau lebih program aplikasi secara optimal, data disimpan tanpa mengalami ketergantungan pada program yang akan menggunakannya, data disimpan sedemikian rupa sehingga apabila ada penambahan, pengambilandan modifikasi data dapat dilakukan dengan mudah dan terkontrol". Menurut Edhy Sutanta (2004:18) Basis data (database) dapat dipahami sebagai "suatu kumpulan data terhubung (interrelated data) yang disimpan secara bersama-sama pada suatu media", tanpa suatu kerangkapan data (kalau pun ada maka kerangkapan data tersebut harus seminimal mungkin dan terkontrol (controlled redudncy), data disimpan dengan cara-cara tertentu, sehingga mudah untuk digunakan/atau ditampilkan kembali; dapat digunakan oleh satu atau lebih program apliksi secara optimal. Dari definisi basis data oleh para ahli diatas maka penulis menyimpulkan bahwa basis data dapat dianggap tempat untuk sekumpulan berkas data terkomputerisasi, dengan tujuan utama memelihara informasi dan membuat informasi tersebut tersedia saat dibutuhkan.

\subsection{Kamus Data}

Menurut Tata Sutabri (2004:172), "Apabila didefenisikan, kamus data adalah katalog fakta tentang data dan kebutuhankebutuhan informasi dari suatu sistem informasi". Kamus data dibuat pada tahap analisis sistem dan digunakan baik tahap analisis maupun pada tahap perancangan sistem. 


\subsection{Pengembangan Aplikasi}

Metode pengembangan aplikasi merupakan serangkaian proses yang dilakukan dari saat ini pembuatan konsep aplikasi sehingga aplikasi tersebut selesai dan siap digunakan. Dalam proses pengembangan aplikasi terdapat berbagai proses yang perlu dilakukan sebagai syarat untuk membuat sebuah aplikasi yang telah terancang dengan baik dan dikerjakan secara terstruktur.

\subsection{Data Flow Diagram (DFD)}

Berikut ini merupakan penjelasan dari beberapa ahli tentang Data Flow Diagram (DFD) yaitu:

Menurut Hartono (2005:700) didalam bukunya Analisis dan desain Sistem Informasi mendifinisikan Data Flow Diagram (DFD) merupakan alat yang digunakan pada metodologi pengembangan sistem yang terstruktur (Structured Analysis and Design) Ada beberapa elemen penyusun DFD yaitu sebagai berikut:

Data Flow

Merupakan suatu data tunggal atau kumpulan logis, suatu data selalu diawali atau berakhir pada suatu proses.

\section{Proses}

Merupakan suatu kegiatan atau kerja yang dilakukan oleh orang, mesin atau komputer dari hasil suatu arus data yang masuk kedalam proses untuk dihasilkan arus data yang akan keluar dari proses.

\section{Data Store}

Merupakan kumpulan data yang disimpan dengan cara tertentu. Data yang mengalir disimpan dalam data store, aliran data diapdate atau ditambahkan ke data stroe.

Tabel 2.1 Daftar elemen-elemen DFD dan Lambangnya

\begin{tabular}{|l|l|}
\hline Simbol & Keterangan \\
\hline
\end{tabular}

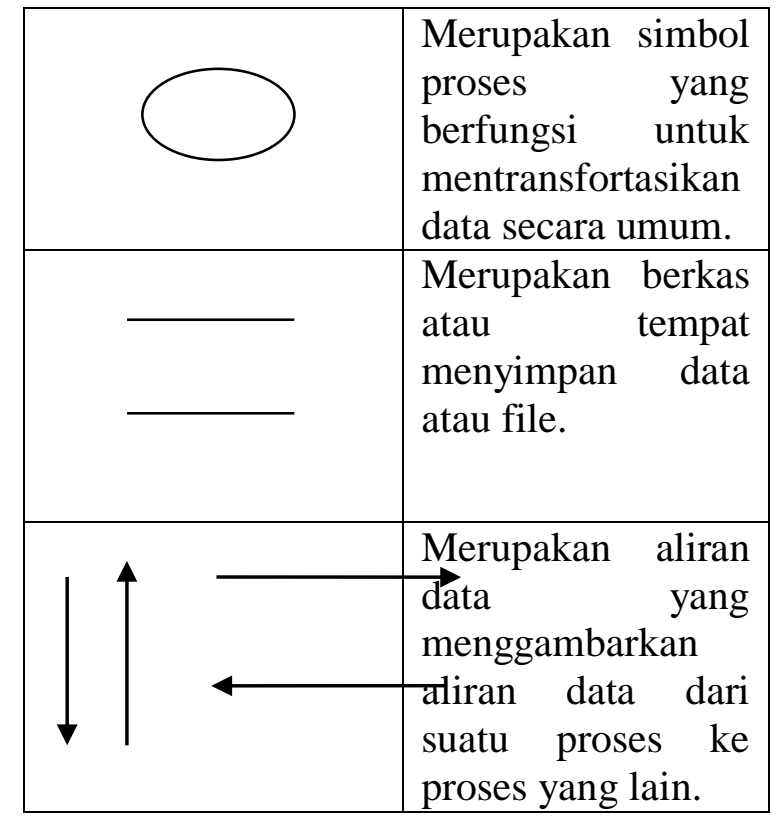

Didalam DFD terdapat 3 level yaitu sebagai berikut :

Diagram Konteks

Diagram konteks merupakan diagram yang menggambarkan suatu lingkaran besar yang dapat mewakili seluruh proses yang terdapat dalam suatu sistem.

Diagram Nol (Diagram level 1)

Diagram nol atau diagram level 1 adalah yang menggambar suatu lingkaran besar yang mewakili lingkaran-lingkaran kecil yang ada didalamnya DFD level 1 merupakan pemecehan dan diagram konteks.

Diagram Rinci

Diagram rinci merupakan proses apa saja yang ada didalam diagram nol.

2. Entity Relationship Diagram (ERD)

Menurut Fatansyah (1999:15) Entity Relationship Diagram (ERD)adalah diagram yang berisi komponen-komponen himpunan entitas dan himpunan relasi yang masingmasing dilengkapi dengan atribut-atribut yang mrmpresentasikan seluruh fakta yang ditinjau. Menurut Mata Taledo dan Cushman (2007:139) mendifinisikan "Entity 
Relantionship Diagram (ERD) merupakan representasi grafis dan logika database dengan menyertakan deskripsi detail mengenai seluruh entitas (entity), hubungan (relationship), dan batasan (constraint)". Berdasarkan penjelasan diatas dapat disimpulkan bahwa ERD merupakan gambaran grafis dari suatu model data yang menyertakan deskripsi detail dari seluruh entity, relationship, dan constraint.

Ada beberapa elemen penyusun ERD yaitu : Entitas (Entity)

Entitas merupakan suatu yang nyata atau abstrak dimana kita akan menyimpan data.

Relasi (Relationship)

Relasi merupakan hubungan alamiah yang terjadi antar satu atau lebih.

Atribut (attribute)

Atribut merupakan ciri umum atau sebagian besar intisari pada entitas tertentu.

Tabel 2.2 Simbol-simbol ERD (Entity Relationship Diagram)

\begin{tabular}{|l|l|}
\hline Notasi & Keterangan \\
\hline \multicolumn{1}{|l|}{} & $\begin{array}{l}\text { Entitas merupakan } \\
\text { suatu yang nyata atau } \\
\text { abstrak dimana kita } \\
\text { akan menyimpan data. }\end{array}$ \\
\hline & $\begin{array}{l}\text { Relasi merupakan } \\
\text { hubungan alamiah yang } \\
\text { terjadi antar satu atau } \\
\text { lebih. }\end{array}$ \\
\hline & $\begin{array}{l}\text { Atribut merupakan ciri } \\
\text { umum atau sebagian } \\
\text { besar intisari pada } \\
\text { entitas tertentu. }\end{array}$ \\
\hline $\begin{array}{l}\text { Garis merupakan } \\
\text { penghubung antara } \\
\text { relasi dengan entitas } \\
\text { relasi dan entitas } \\
\text { dengan atribut. }\end{array}$ \\
\hline
\end{tabular}

\section{Derajat Kardinalitas}

Derajat Kardinalitas merupakan penjelasan dari tingkat hubungan antar entitas. Ukuran derajat kardinalitas dibagi menjadi tiga macam, yaitu:

One-to-one, merupakan sebuah entitas pada A berhubungan dengan paling banyak satu entitas pada B dan sebuah entitas pada B berhubungan dengan paling banyak satu entitas A.

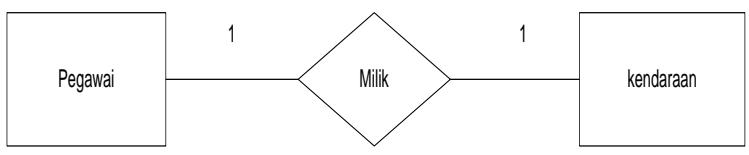

Gambar 2.9 Hubungan One-to-one

One-to-many, adalah sebuah entitas pada A berhubungan dengan nol atau lebih entitas. Sebuah entitas Pada B dapat dihubungkan dengan paling banyak satu entitas pada A.

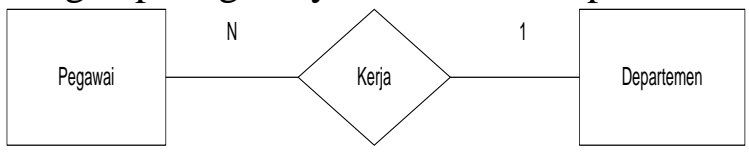

Gambar 2.10 Hubungan One-to-many

Many-to-one, merupakan sebuah entitas pada A dengan paling banyak satu entitas pada B. Sebuah entitas B dapat dihubungkan dengan nol atau lebih entitas pada A.

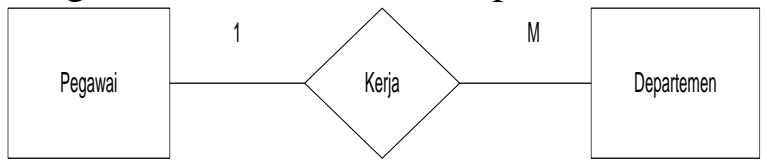

Gambar 2.11 Hubungan Many-to-one

Many-to-many, merupakan sebuah entitas pada A berhubungan dengan nol atau lebih entitas pada B dan sebuah entitas pada B dapat dihubungkan nol atau lebih entitas A.

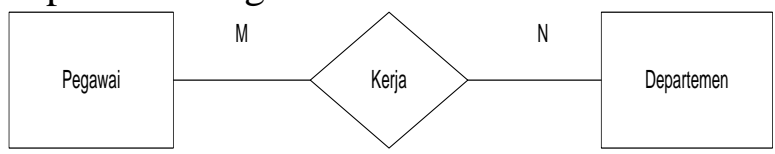

Gambar 2.12 Hubungan Many-to-many

Bagan Alir (flowchart) 


\section{Jurnal Mahasiswa llmu Komputer (JMIK) \\ Vol. 01, No. 01, Maret 2021}

Merupakan Hartono (2005:795) didalalam bukunya "Bagan alir (flowchart) adalah bagan (chart) yang menunjukan alir (flow) di dalam program atau prosedur sistem secara logika.

Tabel 2.3 Simbol-simbol flowchart

\begin{tabular}{|c|c|c|}
\hline No & Simbol & Keterangan \\
\hline 1 & & $\begin{array}{l}\text { Terminal/simbolarus } \\
\text { menunjukan awal mulai dan } \\
\text { akhir dari kegiatan. }\end{array}$ \\
\hline 2 & & $\begin{array}{l}\text { Input/output menunjukan } \\
\text { operasi pembacaan input atau } \\
\text { pencetakan output. }\end{array}$ \\
\hline 3 & & $\begin{array}{l}\text { Input/output kartu (kartu plong) } \\
\text { menunjukan media input output } \\
\text { menggunakan kartu plong. }\end{array}$ \\
\hline 4 & & $\begin{array}{l}\text { Input/output Dokumentasi } \\
\text { digunakan untuk pembacaan } \\
\text { input melalui optical scanner } \\
\text { atau pencetakan output pada } \\
\text { printer. }\end{array}$ \\
\hline 5 & & $\begin{array}{l}\text { Pengolahan/simbol proses } \\
\text { menunjukan suatu pengolahan } \\
\text { yang dilakukan komputer. }\end{array}$ \\
\hline 6 & & $\begin{array}{l}\text { Simbol Keputusan menunjukkan } \\
\text { suatu seleksi yang harus } \\
\text { dikerjakan. }\end{array}$ \\
\hline
\end{tabular}

\begin{tabular}{|c|c|}
\hline 7 & $\begin{array}{l}\text { Simbol proses terdefinisi } \\
\text { menunjukan sejumlah proses } \\
\text { yang detailnya tidak ditunjukan } \\
\text { disini, tetapi terdefinisi sendiri, } \\
\text { berupa program bagian (sub- } \\
\text { routine) }\end{array}$ \\
\hline 8 & $\begin{array}{lrr}\text { Simbol Garis Alir } & \text { yaitu } \\
\text { digunakan } & & \text { untuk } \\
\text { menghubungkan arah } & \text { tujuan } \\
\text { simbol-simbol flowchart yang } \\
\text { satu dengan yang lainnya. }\end{array}$ \\
\hline 9 & $\begin{array}{l}\text { Simbol penghubung halaman } \\
\text { yang sama, apabila flowchart } \\
\text { terpotong dan masih } \\
\text { mempunyai sambungan dalam } \\
\text { halaman yang sama digunakan } \\
\text { simbol ini. }\end{array}$ \\
\hline 10 & $\begin{array}{l}\text { Simbol baris penghubung bila } \\
\text { flowchart terpotong dan masih } \\
\text { mempunyai sambungan pada } \\
\text { halaman berikutnya, digunakan } \\
\text { simbol ini. }\end{array}$ \\
\hline 11 & $\begin{array}{l}\text { Simbol /magnetic tape unit } \\
\text { (Simbol pita magnetik) } \\
\text { menunjukkan alat input/output } \\
\text { berupa tape output. }\end{array}$ \\
\hline 12 & $\begin{array}{l}\text { Simbol mini desk (Diskete) } \\
\text { menunjukkan alat input/output } \\
\text { berupa mini disk atau diskette, } \\
\text { floopy, flexybel disk. }\end{array}$ \\
\hline 13 & $\begin{array}{l}\text { Magnetic Disk merupakan alat } \\
\text { input/output berupa disk } \\
\text { magnetis (hard disk). }\end{array}$ \\
\hline 14 & $\begin{array}{l}\text { Magnetic drum menunjukkan } \\
\text { alat input/output berupa drum } \\
\text { magnetis. }\end{array}$ \\
\hline
\end{tabular}




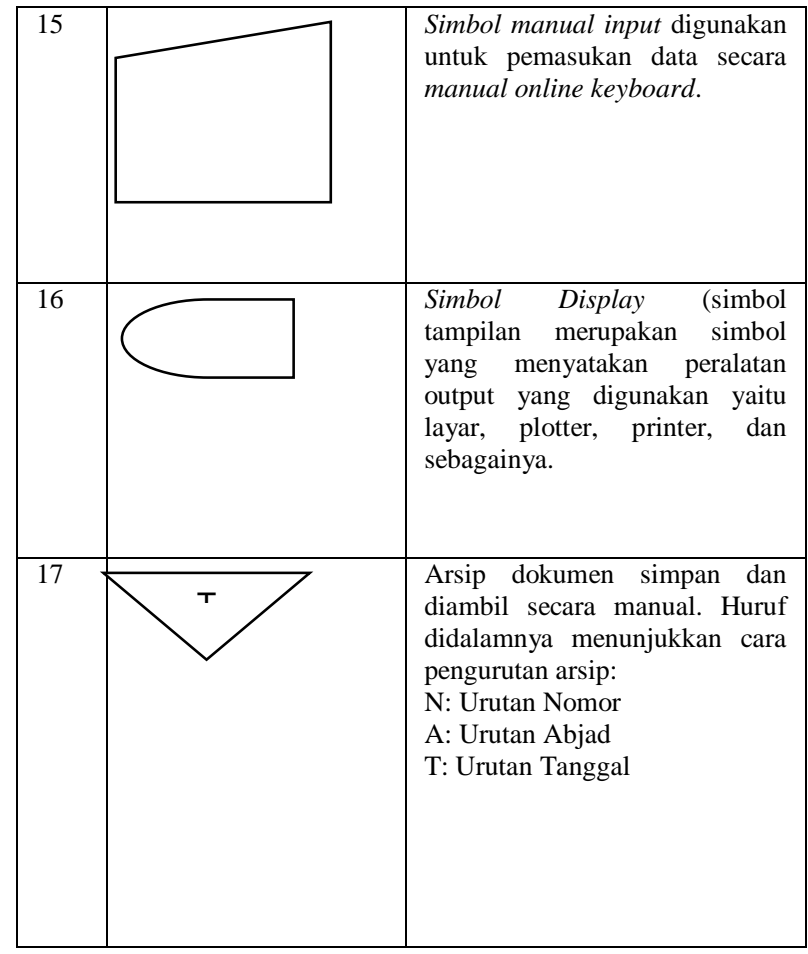

\section{METODE}

Dalam memperoleh data untuk menyusun tugas akhir ini, penulis menggunakan metode yaitu :

\section{Studi Lapangan}

Studi Lapangan adalahpengumpulan secara langsung mempelajari sebuah sistem yang berkaitan dengan masalah yang sedang yang sedang dihadapi. Adapun studi lapangan yang penulis lakukan dengan teknik:

\section{$\sqrt{ }$ Pengamatan (Observation)}

Yaitu dengan cara melakukan penelitian secara langsung pada Dinas Komunikasi dan Informatika Kota Metro, sehingga penulis mengetahui alur sistem kerja yang berjalan saat ini.

\section{$\sqrt{ }$ Wawancara(Interview)}

Wawancara yaitu mengumpulkan data-data dengan cara melakukan tanya jawab atau tatap muka secara langsung dengan pegawai yang bekerja dibagian Kasubbag dilingkungan penelitian.

$\sqrt{ }$ Dokumentasi (Documentation)

Penulis membutuhkan tambahan data sebagai pelengkap tugas akhir dengan cara mengumpulkan dokumentasi yang terkait.

2. Studi Pustaka

Studi Pustaka merupakan pengumpulan data dengan cara membaca buku-buku, dan mempelajari sistem kerja yang berkaitan dengan penelitian.

\section{PEMBAHASAN}

\subsection{Hasil Penelitian}

Sistem pendataan pegawai pada Dinas Komunikasi dan Informatika Kota Metro sudah terkomputerisasi dalam pendataan data pegawai diolah menggunakan Ms.Excel, pendataan data pegawai dalam penulisan dan pembuatan tabel pendataan pegawai tersebut terkadang terjadi kesalahan, pencarian data pegawai kurang efektif karena harus mencari satu persatu data pegawai pada Ms.Excel yang kurang 
efisien waktu, hal ini dapat menyebabkan proses pendataan pegawai serta pembuatan laporan data pegawai kurang efektif. Jadi perlu adanya sistem pendataan pegawai dalam bentuk sebuah aplikasi yang dapat mempermudah pekerjaan dan mampu menyajikan data atau informasi yang sesuai kebutuhan.

\section{Tujuan Perancangan Sistem}

Tujuan perancangan sistem ini adalah memperbaiki sistem pendataan pegawai di Dinas Komunikasi dan Informatika Kota Metro. Perancangan ini diusulkan sebagai bahan masukan yang dapat dipertimbangkan untuk meningkatkan efektifitas kerja petugas pendataan pegawai.

\section{Gambaran Umum Sistem Yang Diusulkan}

Sistem aplikasi yang diusulkan memiliki beberapa keunggulan dari sistem yang sedang berjalan. Sistem yang diusulkan lebih mudah digunakan, lebih menghemat waktu dalam proses perekapan data pegawai, lebih aman tersimpan dalam database. Sehingga dapat mempermudah dalam proses pencarian data dan cetak data.

3. Perancangan Prosedur Yang Diusulkan
Pada tahapan perancangan prosedur ini bertujuan untuk menghasilkan perancangan aplikasi pendataan data pegawai menggunakan database. Adapun perancangan proses ini mencangkup diagram konteks, data flow diagram, flowchart, yang dapat menjelaskan aliran data yang diproses hingga menghasilkan informasi yang diinginkan.

\section{A. Aliran Informasi Yang Diusulkan}

Aliran informasi yang diusulkan tidak merubah tujuan ataupun fungsi dari sistem yang berjalan. Beberapa perubahan didalam proses pendataan pegawai dilakukan untuk membuat sistem yang lebih baik.

1. Rancangan Diagram Konteks Aplikasi Perancangan Pendataan Data Pegawai Menggambarkan rancangan aplikasi data pegawai pada Dinas Komunikasi dan Informatika Kota Metro serta pihak-pihak yang terlibat di dalamnya.

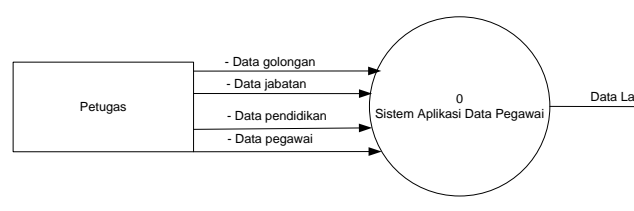


Jurnal Mahasiswa IImu Komputer (JMIK)

Vol. 01, No. 01, Maret 2021

2. Rancangan Data Flow Diagram Aplikasi Pendataan DataPegawai

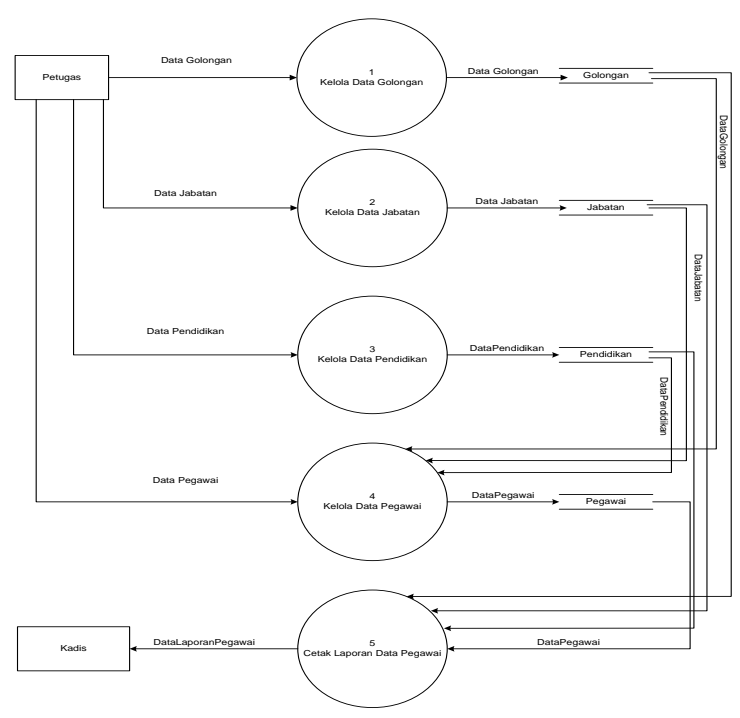

Gambar 4.2 Rancangan DFD Level 1 Aplikasi Pendataan Data Pegawai

3. Rancangan Bagan Alir Dokumen Aplikasi Pendataan Data Pegawai

Menjelaskan rancangan bagan alir dokumendokumen, proses-proses serta pihak-pihak yang terlibat didalamnya.

Tabel 4.1 flowchart pendataan pegawai yang diusulkan pada

Dinas Komunikasi dan Informatika Kota Metro

\section{Rancangan Entity Relatinship Diagram (ERD)}

ERD dibuat untuk menggambarkan atau membuat model suatu database dengan diagram yang sederhana sehingga memudahkan dalam membuat sebuah database yang kompleks maupun yang sederhana. Berikut adalah rancangan ERD yang dijelaskan. 


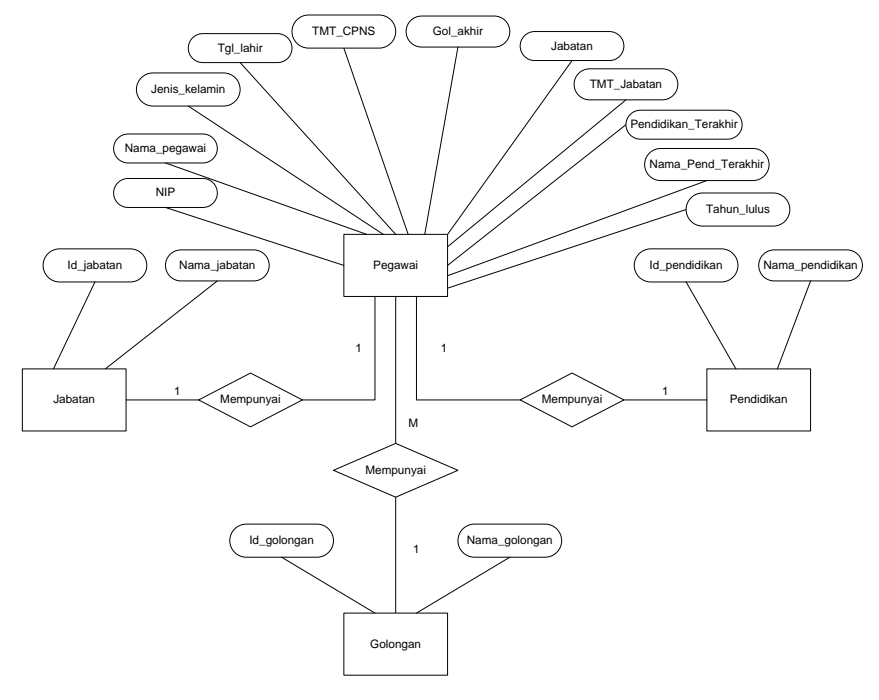

Gambar 4.3 ERD Perancangan Aplikasi

Pendataan Data Pegawai

\section{B. Rancangan Basis Data}

Basis data atau databasse adalah kumpulan file atau tabel untuk kaitannyadengan program ini. Untuk menyimpan data pegawai di Dinas Komunikasi dan Informatika Kota Metro diperlukan sebuah database.

Nama database : ta

Berikut adalah tabel-tabel dalam database ta

1. Tabel Golongan

Tabel Golongan digunakan untuk menyimpan data golongan.

Nama Tabel : tbgolongan

Primary Key : Id_golongan
Jumlah field $\quad: 2$

Keterangan : Berisi data

golongan

Tabel 4.2 Tabel Golongan

\begin{tabular}{|l|l|l|l|l|}
\hline Field & $\begin{array}{l}\text { Typ } \\
\text { e }\end{array}$ & $\begin{array}{l}\text { Si } \\
\text { ze }\end{array}$ & $\begin{array}{l}\text { Pri } \\
\text { mar } \\
\mathbf{y}\end{array}$ & $\begin{array}{l}\text { Ketera } \\
\text { ngan }\end{array}$ \\
\hline $\begin{array}{l}\text { Id_golon } \\
\text { gan }\end{array}$ & $\begin{array}{l}\text { Inte } \\
\text { ger }\end{array}$ & 5 & Yes & $\begin{array}{l}\text { Primar } \\
\text { Key }\end{array}$ \\
\hline $\begin{array}{l}\text { Nama_g } \\
\text { olongan }\end{array}$ & $\begin{array}{l}\text { Var } \\
\text { char }\end{array}$ & 50 & & $\begin{array}{l}\text { Nama } \\
\text { golong } \\
\text { an }\end{array}$ \\
\hline
\end{tabular}

2. Tabel Jabatan

Tabel Jabatan digunakan untuk menyimpan data jabatan.

Nama Tabel : tbjabatan

Primary Key : Id_jabatan

Jumlah field $\quad: 2$

Keterangan : Berisi data jabatan

\section{Tabel 4.3 Tabel Jabatan}

\begin{tabular}{|l|l|l|l|l|}
\hline Field & Type & $\begin{array}{l}\text { Siz } \\
\text { e }\end{array}$ & $\begin{array}{l}\text { Prima } \\
\text { ry }\end{array}$ & $\begin{array}{l}\text { Keteran } \\
\text { gan }\end{array}$ \\
\hline Id_jabatan & $\begin{array}{l}\text { Intege } \\
\text { r }\end{array}$ & 5 & Yes & $\begin{array}{l}\text { Primary } \\
\text { Key }\end{array}$ \\
\hline $\begin{array}{l}\text { Nama_jab } \\
\text { atan }\end{array}$ & Varch & 10 & & $\begin{array}{l}\text { Nama } \\
\text { jabatan }\end{array}$ \\
\hline
\end{tabular}

3. Tabel Pendidikan

Tabel pendidikan digunakan untuk menyimpan data pendidikan.

Nama Tabel : tbpendidikan 

Primary Key : :
Id_pendidikan
Jumlah field
$: 2$
Keterangan
: Berisi data
pendidikan

\section{Tabel 4.4 Tabel Pendidikan}

\begin{tabular}{|l|l|l|l|l|}
\hline Field & Type & Size & Primary & Ket \\
\hline Id_pendidikan & Integer & 5 & Yes & P \\
& & & & \\
\hline Nama_pendidikan & Varchar & 50 & & N \\
& & & & \\
\hline
\end{tabular}

4. Tabel Pegawai

Tabel pegawai digunakan untuk

menyimpan data pegawai.

Nama Tabel : tbpegawai

Primary Key : : Nip

Jumlah field $\quad: 11$

Keterangan : Berisi data

pegawai

\begin{tabular}{|l|l|l|l|l|c|}
\hline Pend_akhir & varchar & 20 & & & Fore \\
\hline Id_pendidikan & Integer & 5 & & Yes & Fore \\
\hline Thn_lulus & Integer & 11 & & & Fore \\
& & & & & \\
\hline
\end{tabular}

\section{Relasi Tabel}

Dalam membangun sebuah aplikasi, perlu dilakukan perancangan struktur relasi antara tabel yang diperlukan untuk menggambarkan hubungan antara tabel. Rancangan relasi tabel yang dibuat penulis mencangkup nama tabel, relasirelasi tabel, atribut/nama field, primary key, dan foreing key. Dalam database ini terdapat 4 tabel. Rancangan relasi antar tabel.

Tabel 4.5 Tabel Pegawai

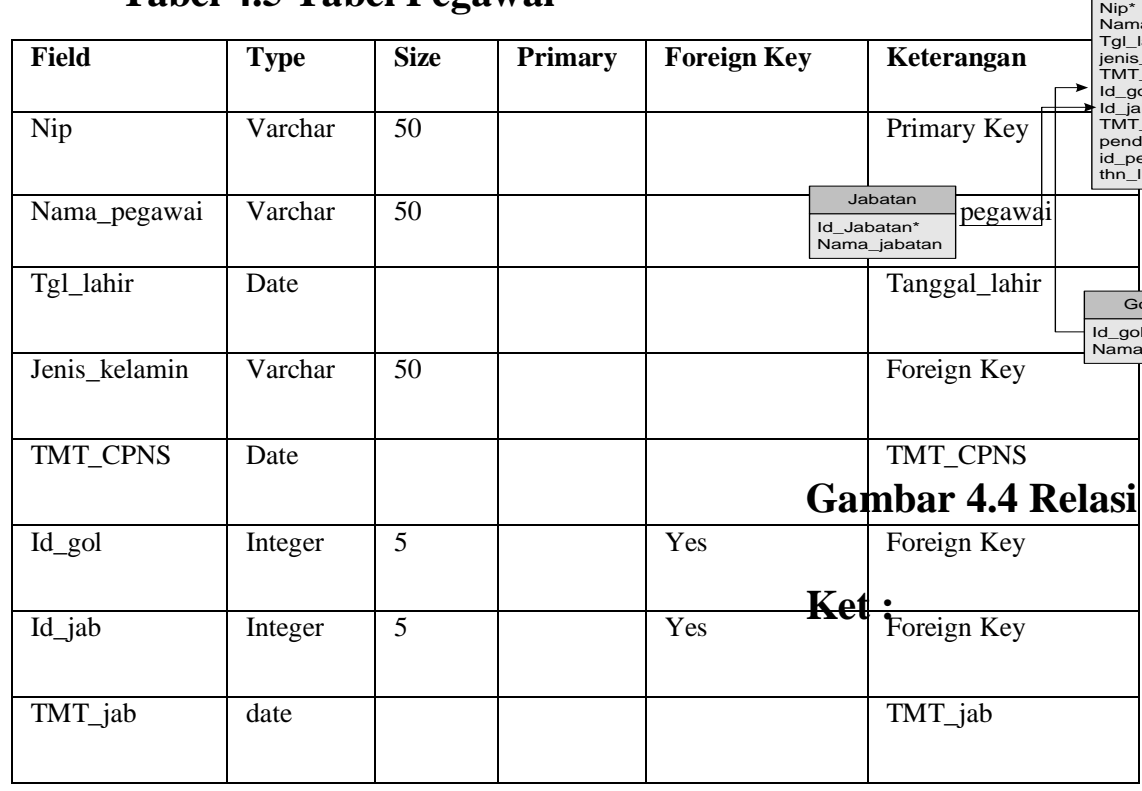


* : Primary Key adalah field kunci / utama dari suatu tabel yang menunjukkan bahwa field yang menjadi kunci tersebut tidak bisa diisii dengan data yang sama, /dengan kata lain Primary key menjadi tiap record memiliki identitas sendiri-sendiri yang membedakan satu sama lainnya (unik).

** : Foriegn key adalah suatu attribute yang melengkapi satu relationship yang menunjukan ke induknya.

\section{Rancangan Antar Muka Sistem}

Rancangan antar muka input dan output sistem merupakan rancangan fisik yang digunakan untuk menginputkan data dan menampilkan data, serta memberikan informasi kepada user atau pengguna.

\section{Rancangan Tampilan Halaman Utama}

Rancangan tampilan Halaman Utama.

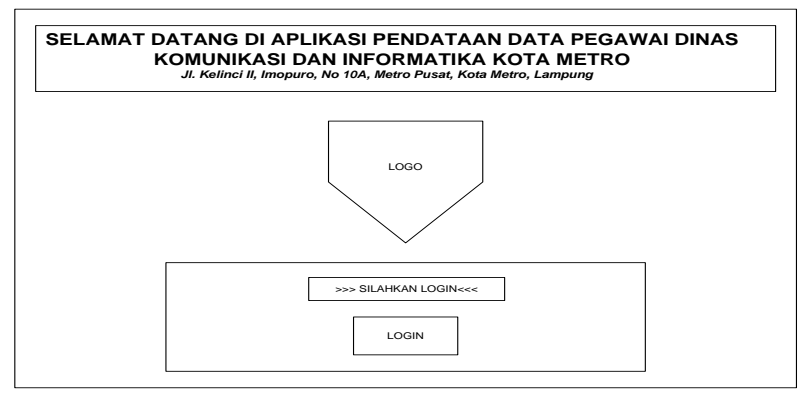

Gambar 4.5 Halaman Utama

\section{Rancangan Tampilan Login}

Rancangan tampilan login user .

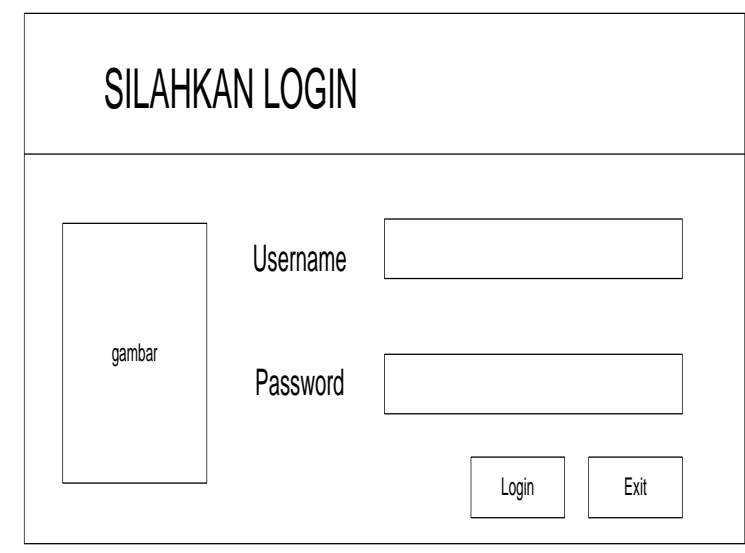

\section{Gambar 4.6 halaman login}

\section{Rancangan Tampilan Menu Utama}

Rancangan tampilan menu utama.

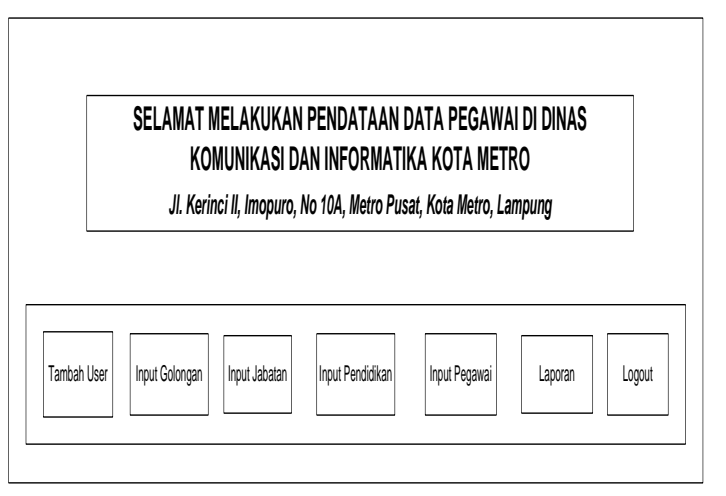

Gambar 4.7 halaman menu utama

\section{Rancangan Halaman Input Data Golongan}

Rancangan tampilan halaman input data golongan. 
Jurnal Mahasiswa IImu Komputer (JMIK)

Vol. 01, No. 01, Maret 2021

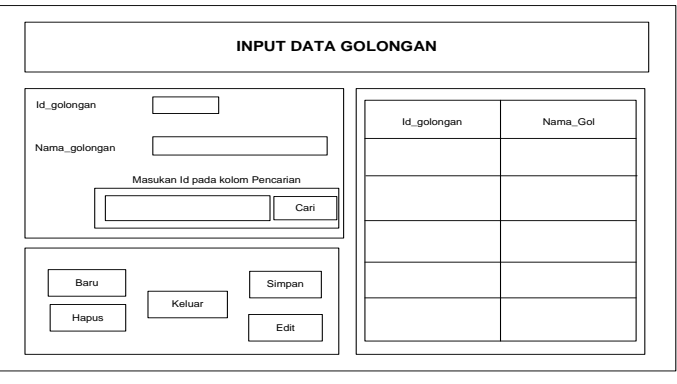

Gambar 4.8 halaman input data golongan

\section{Rancangan Halaman Input Data Jabatan}

Rancangan tampilan halaman input data jabatan

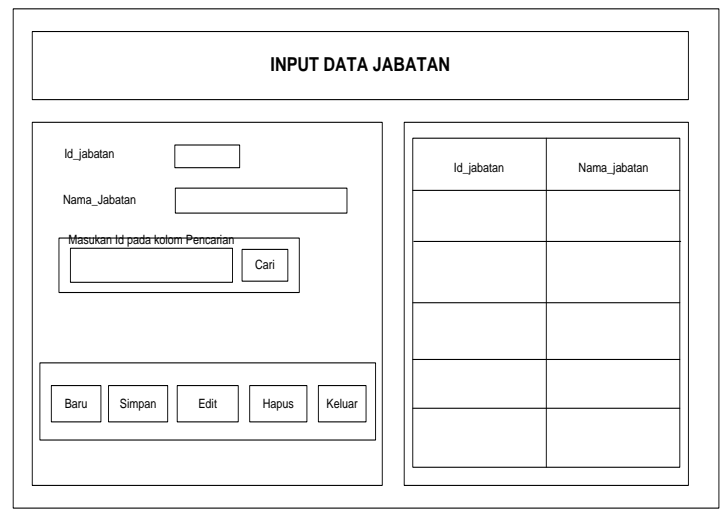

Gambar 4.9 halaman input data jabatan

\section{Rancangan Halaman Input Data Pendidikan}

Rancangan tampilan halaman input data pendidikan

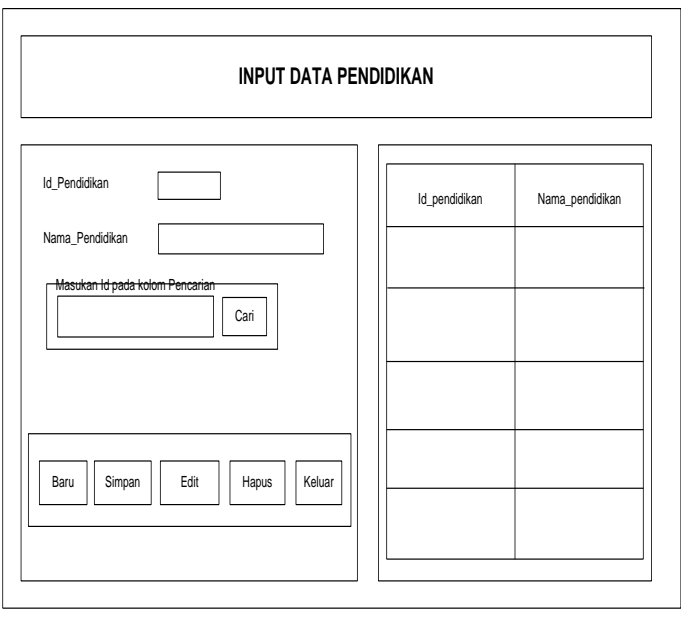

Gambar 4.10 halaman input data pendidikan

\section{Rancangan Halaman Input Data Pegawai}

Rancangan tampilan halaman input data pegawai

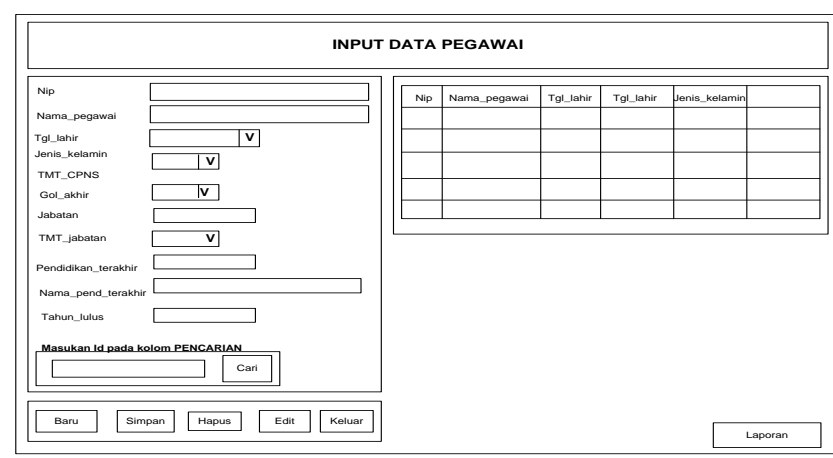

Gambar 4.11 halaman input data pegawai

\section{Rancangan Halaman Laporan Data Pegawai}

Rancangan tampilan halaman laporan data pegawai pergolongan dan keseluruhan. 


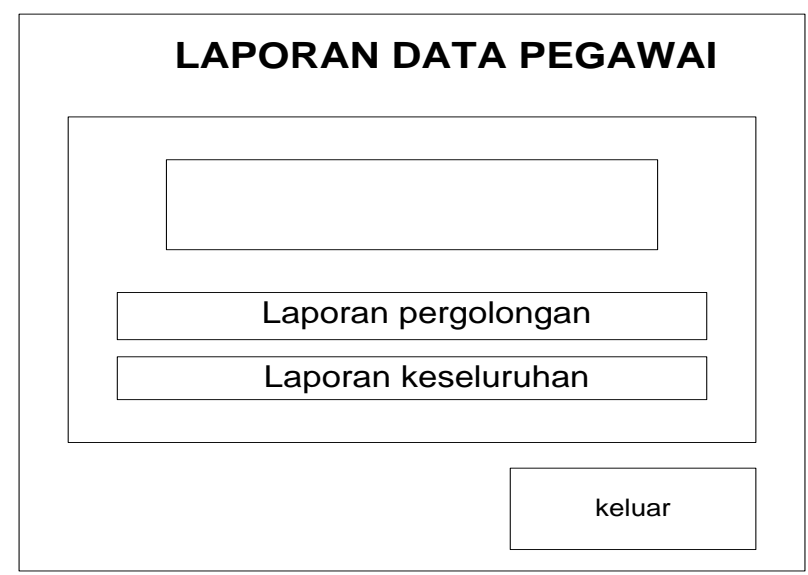

\section{Gambar 4.12 halaman laporan data} pegawai

\section{Rancangan Cetak Data Pegawai}

Rancangan cetak laporan data pegawai keseluruhan

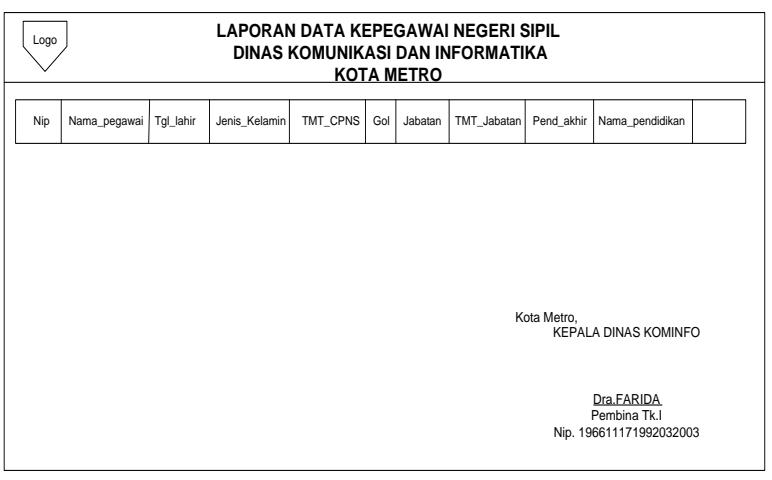

Gambar 4.13 cetak laporan data pegawai

\section{Pembahasan Program}

\section{Tampilan Halaman Utama}

Tampilan ini berfungsi untuk akses masuk ke Login.

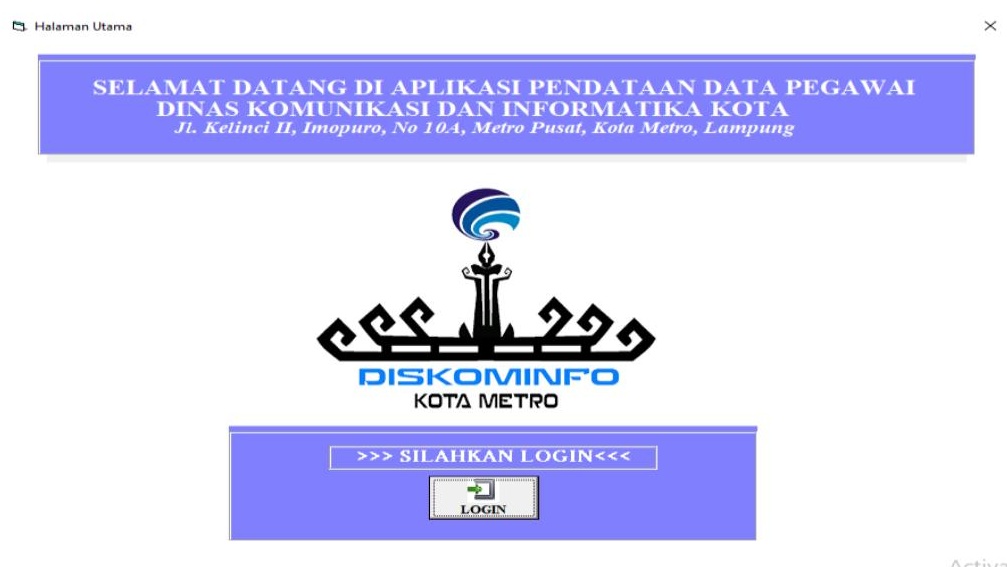

\section{Gambar 4.14 Halaman Utama}

\section{Tampilan User}

Tampilan ini berfungsi untuk masuk ke menu utama.

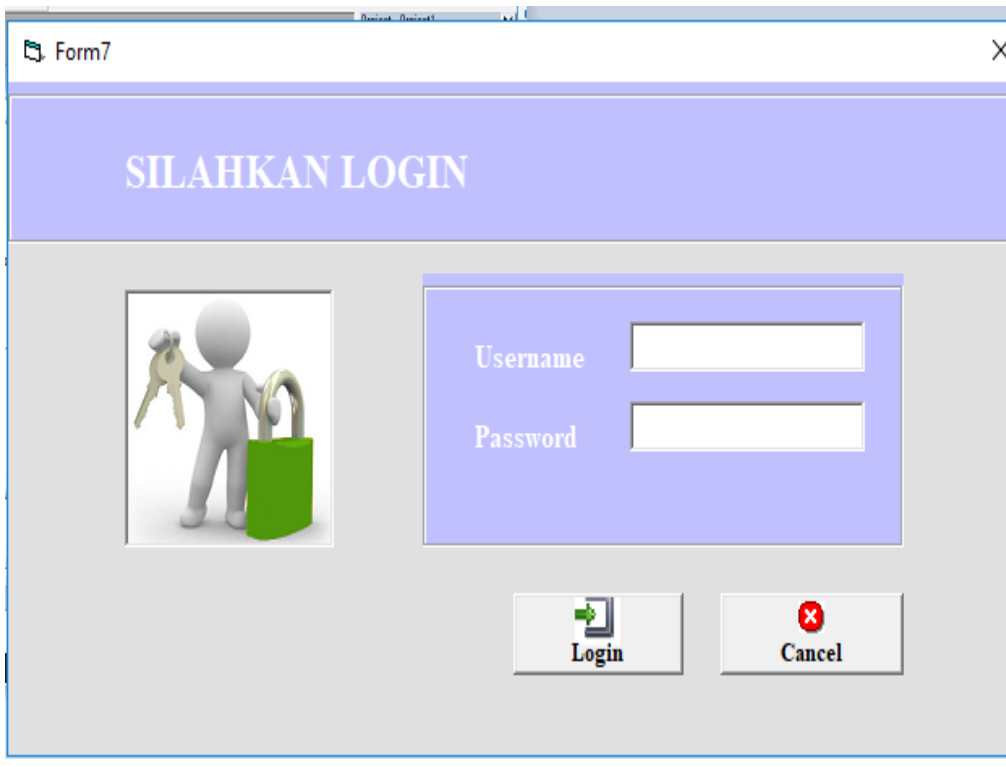

\section{Gambar 4.15 Halaman Login}

\section{Tampilan Menu Utama}


Halaman menu utama berfungsi untuk menggabungkan form-form agar dapat diakses dengan mudah.
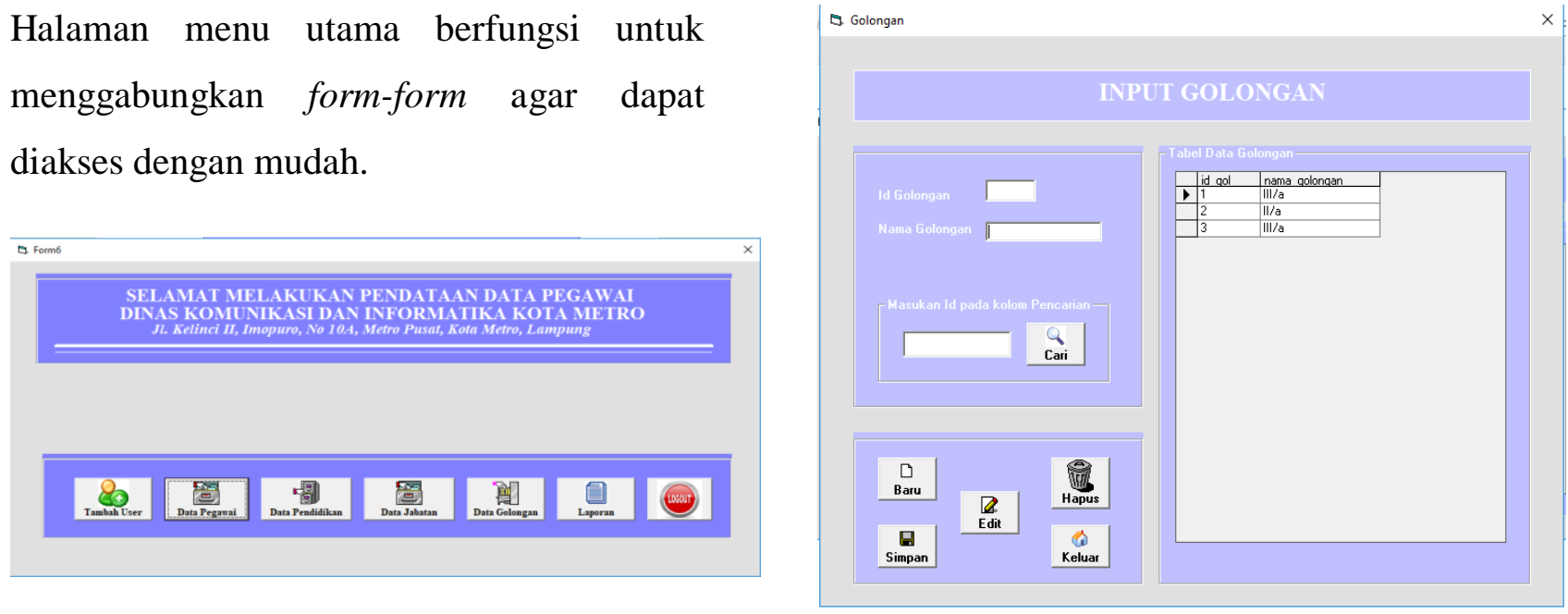

\section{Gambar 4.16 Menu Utama}

\section{TampilanTambah User}

Berfungsi untuk menambah user atau admin baru.

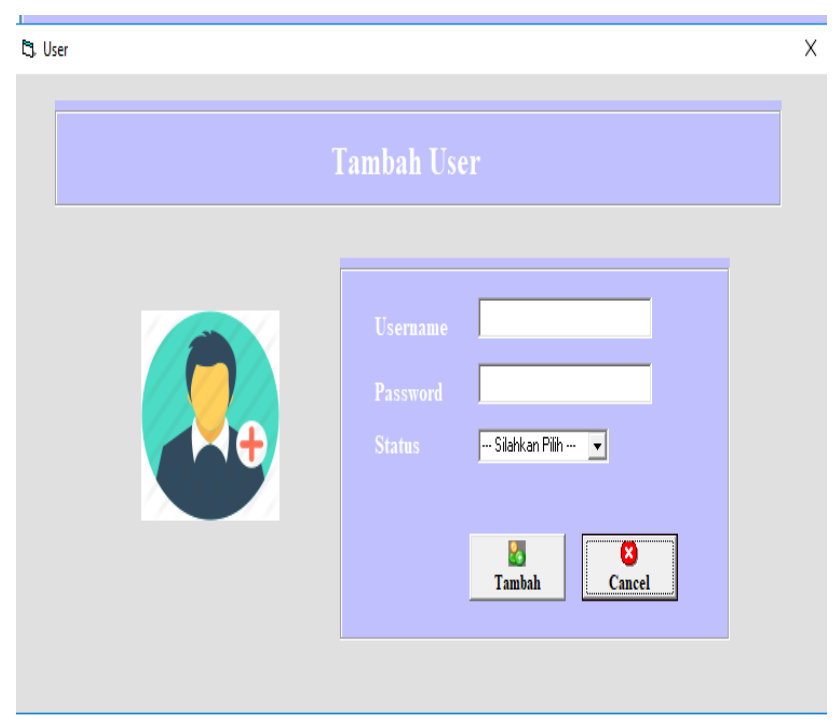

\section{Gambar 4.18 Form data golongan}

\section{Tampilan Form Data Jabatan}

Berfungsi untuk mengelola data jabatan.

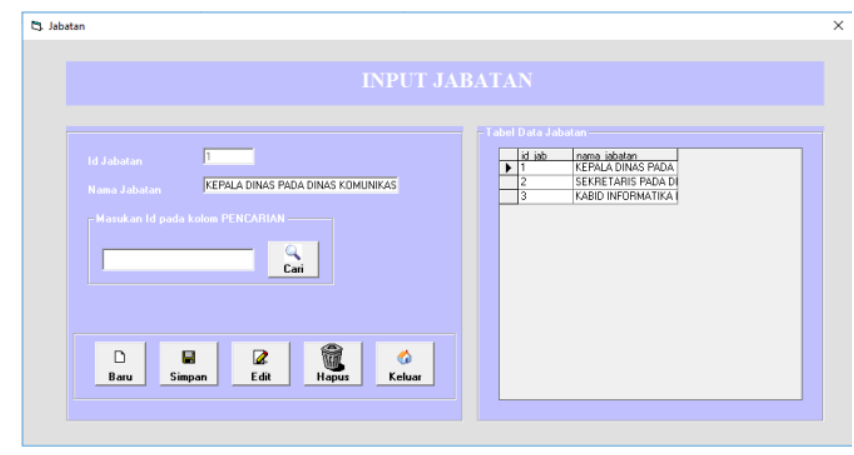

\section{Gambar 4.19 Form data jabatan}

\section{Tampilan Form Data Pendidikan}

Berfungsi untuk mengelola data pendidikan.

\section{Gambar 4.17 Tampilan Tambah User}

\section{Tampilan Form Data Golongan}

Berfungsi untuk mengelola data golongan. 


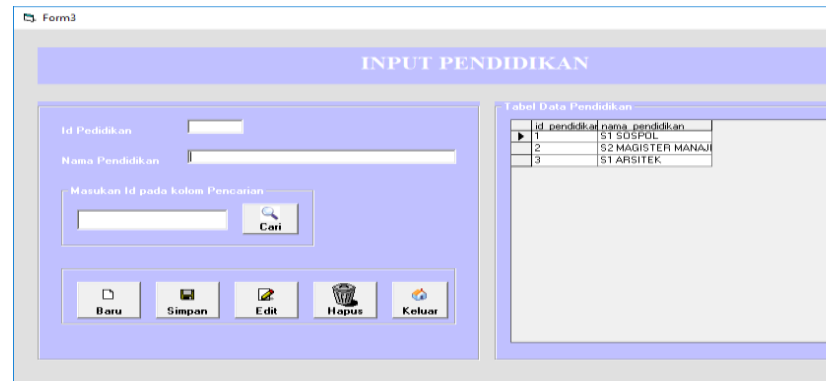

Gambar 4.20 Form data pendidikan

\section{Tampilan Form Data Pegawai}

Berfungsi untuk mengelola data pegawai.

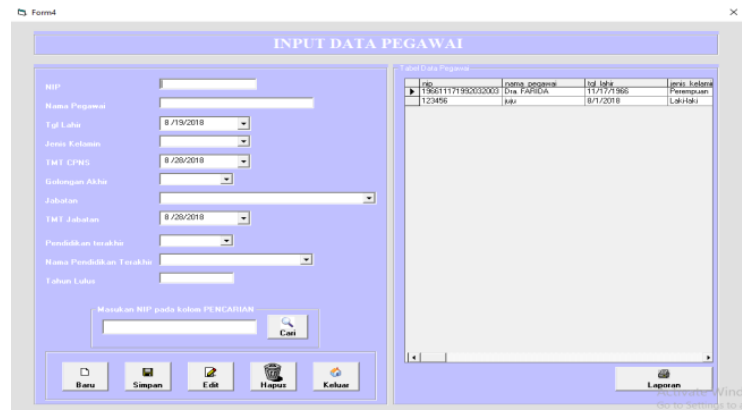

Gambar 4.21 Form data pegawai

\section{Tampilan Form Laporan Data Pegawai}

Berfungsi untuk melihat laporan data pegawai pergolongan atau keseluruhan.

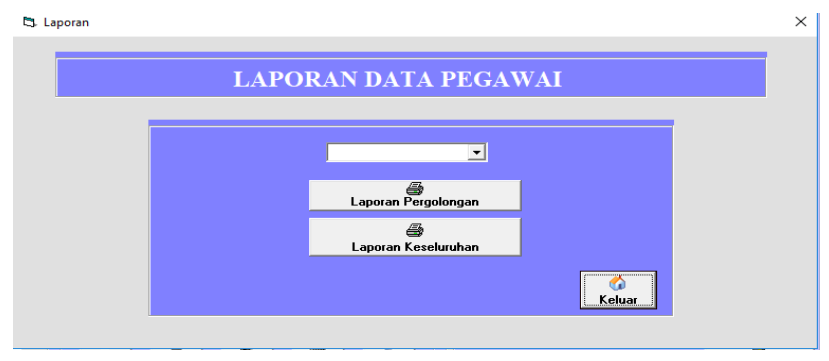

\section{Gambar 4.22 form Laporan Data \\ Pegawai}

\section{Tampilan Preview Cetak Data Pegawai Pergolongan}

Berfungsi menampilkan data pegawai pergolongan yang akan dicetak.

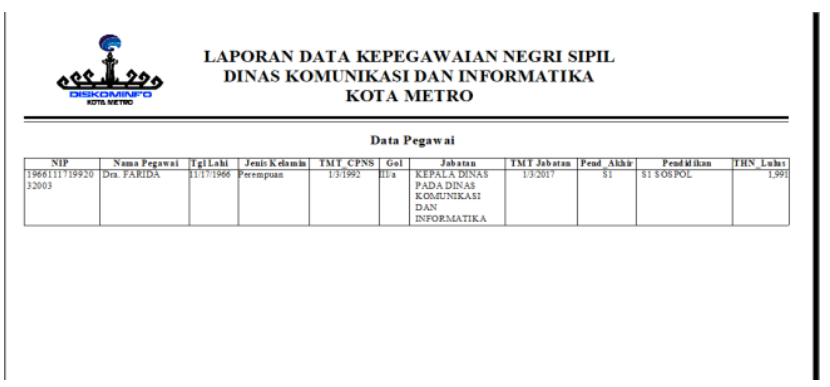

\section{Gambar 4.23 Preview Cetak Data Pegawai Pergolongan}

\section{Tampilan Preview Cetak Data Pegawaikeseluruhan}

Berfungsi menampilkan data pegawai keseluruhan yang akan dicetak.

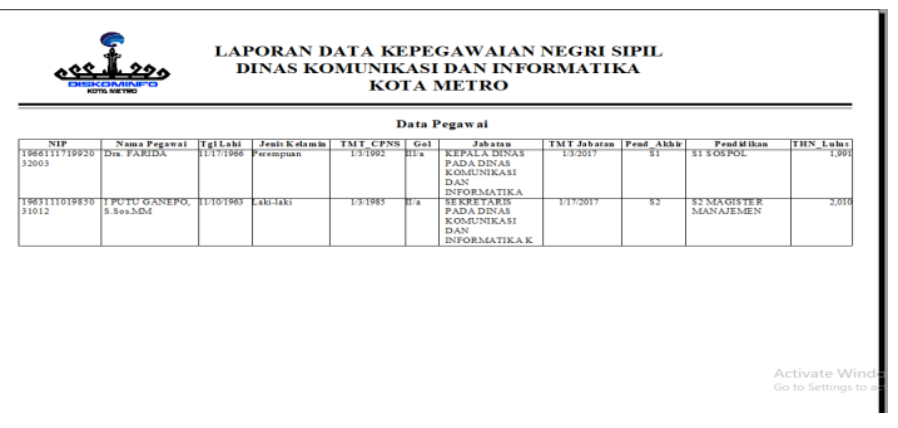

\section{Gambar 2.24 Preview Cetak Data Pegawai keseluruhan \\ E. Kelebihan Dan Kekurangan Program}


Program yang dirancang penulis memiliki kelebihan dan kekurangan. Adapun kelebihan dan kekurangan program yang telah dirancang adalah sebagai berikut.

\section{Kekurangan}

Program yang dirancang penulis memiliki beberapa kelemahan, yaitu:

a. Harus menginput data satu persatu seperti form golongan, jabatan, dan pendidikan terlebih dulu sebelum menginput form pegawai.

b. Tampilan terlalu sederhana.

\section{Kelebihan}

Program yang dirancang penulis memiliki beberapa kelemahan, yaitu:

a. Dalam pengolahan data pegawai lebih efektif karena sudah menggunakan database sebagai media penyimpanan untuk menggantikan system lain.

b. Proses perekapan data pegawai juga lebih efektif dikarenakan petugas tidak perlu lagi membuat table pada Ms.Excel.

c. Pencarian data lebih cepat.

\section{KESIMPULAN}

1. Kesimpulan
Setelah memahami dan menganalisis masalah yang terjadi maka penulis dapat merancang Aplikasi data pegawai pada Dinas Komunikasi dan Informatika Kota Metro. Sehingga dapat diambil beberapa kesimpulan sebagai berikut:

$\sqrt{ }$ Hasil perancangan aplikasi data pegawai pada Dinas Komunikasi dan Informatika Kota Metro dapat mempermudah dalam pendataan data.

$\sqrt{ }$ Dengan adanya aplikasi data pegawai yang menggunakan aplikasi Misrosoft Visual Basic 6.0 dapat membantu petugas kassubag Dinas Komunikasi dan Informatika Kota Metro dalam pencarian data pegawai agar lebih efektif dan menghemat waktu.

$\sqrt{ }$ Dengan adanya aplikasi data pegawai pada Dinas Komunikasi dan Informatika Kota Metro dalam pembuatan laporan data pegawai agar lebih efektif.

\section{Saran}

Berdasarkan kesimpulan diatas penulis memiliki saran sebagai berikut:

$\sqrt{ }$ Dalam pembuatan aplikasi ini, penulis berharap agar aplikasi ini dapat dikembangkan menjadi lebih baik lagi kedepannya dan penulis membuat aplikasi ini sesuai dengan pengamatan yang dilakukan di Dinas Komunikasi dan Informatika Kota Metro.

$\sqrt{ }$ Pengetahuan terhadap sistem perlu diperhatikan agar sistem ini dapat dioperasikan secara maksimal.

$\sqrt{ }$ Jika dalam pembuatan aplikasi ini terdapat suatu kekurangan, khususnya dalam hal desain antar muka penulis berharap untuk pengembangan lebih lanjut dapat ditingkatkan. 


\section{DAFTAR PUSTAKA}

[1] Arman, 2015. Sistem Informasi Pengolahan Data Penduduk Nagari Tanjung Lolo, Kecamatan Tanjung Gadang, Kabupaten Sijunjung berbasis Web. Jurnal Edik Informatika Penelitian Bidang Komputer Sains dan Pendidikan Informatika Vol.2 : 163-170. ISSN: 2407-0491.

[2] Enterprise Jubilee, 2017. Visual Bsic Komplet. Yogyakarta: PT Elex Media Komputindo.

[3] Faizal, Edi Irnawati. 2015. Pemrograman Java Web. Yogyakarta : Gava Media

[4] H.M, Jogiyanto. 2005. Analisis \& Desain. Yogyakarta: Andi Offset.

[5] H.M, Jogiyanto. 1999. Pengenalan Komputer. Yogyakarta: Andi Offset.

[6] Irnawan. 2006. Memahami Pemrograman Delphi 7. Jakarta: BSI PRESS

[7] Lumbanbatu Katen, dan Novriyeni. 2004. Perancangan Informasi Penyebaran Penduduk Menggunakan PHP MySQL Pada Kecamatan Bijay Selatan. Jurnal Kaputama, Vol.7. No.1. ISSN: 1979-6641.

[8] Prasetyo Ekkal, 2010. Sistem Informasi Dokumentasi Dan Kearsipan Berbasis Client-Server Pada Bank Sumsel Babel Cabang Sekayu.

[9] Jurnal Teknik Informatika Politeknik Sekayu, Vol.7. No.2. ISSN: 2407-2192
[10] Purba, Marina. 2017. Perancangan Aplikasi Penjualan pada PT.Mustrakom. Jurnal Informatika. Vo.6. No.1. ISSN : 2301-5632.

[11] Ridhawati, Eka dan khumaid. 2015. Aplikasi sistem informasi pemesanan pupuk berbasis sms gateway pada gabungan petani pemakai pupuk (gp3) pekon banding agung kecamatan talang padang. Jurnal Manajemen Sistem Informasi dan Teknologi Vol.5. No.2 48-52. ISSN: 20885555 .

[12] Sembiring, Hermansyah (dkk). 2012. Sistem Informasi Jumlah Angkatan Kerja Menggunakan Visual Basic Pada Badan Statistik (BPS) Kabupaten Langkat. Jurnal KAPUTAMA. Vol.5. No.2. ISSN : 19796641.

[13] Sofyan, Asep, Abdul (dkk). 2015. Perancangan Aplikasi Sistem Pakar Deteksi Dini Kerusakan Mobil Toyota Avanza. Jurnal Sisfotek Global, Vol.5. No.1. ISSN: 20881762. 